\title{
Toward a New Administrative Doctrine: Governance and Management for the 1990's
}

\author{
Ralph P. Hummel \\ University of Oklahoma
}

\begin{abstract}
Three successive terms of market-oriented presidents raise difficulties for federal bureaucrats in legitimating past administrative doctrine and practices, which were government-centered. The present article responds to Charles Levine's call for a new administrative doctrine that is more fully descriptive of the needs and routines of today's federal civil servants than a doctrine based on either a liberal or neo-conservative ideology. The author introduces the concept of doctrine into public administration discourse in order to clarify the differences in ideology, doctrine, and practices between an era of top-down liberal progressivism and the era of bottom-up neo-conservative progressivism that dawned with the first Reagan administration. The purpose is to take a first step in describing emerging administrative realities that both traditional bureaucrats and free-marketeers must recognize.
\end{abstract}

What shall government do? How should it be doing it? Who should be doing it? ${ }^{1}$

The absence of a clear-cut answer to these questions signals not only an era of political transition for citizens but the absence of explicit administrative doctrine that could guide civil servants through the changed conditions of the times. "Governments worldwide, including the United States, have changed in both their ends and means since the Brownlow and Hoover commissionsand will surely change more before the next century." So said Charles $\mathrm{H}$. Levine (1985: 31) in concluding a recent look ahead to the year 2000. What is needed, he said, is "a new, consistent doctrine to guide efforts to improve governance and management." He added that "Shaping such a doctrine is perhaps the central challenge confronting scholars and public officials in the next decade and a half and can be their most valuable contribution to the public interest of the future."

In the face of three terms of presidents whose ideology has differed radically from the ideology that gave rise to traditional public administration, public servants need to question the political viability of time-hallowed doctrine that guides their behavior; in fact, ideological change in the presidency may be revealing, in a first major challenge since the days of Franklin Delano Roosevelt, that the federal bureaucracy works not on the basis of unalterable science or natural art but on the basis of doctrine for which there are alternatives. What, then, is doctrine and how are its basis and content changing in American public service?

American Review of Public Administration Volume 19, Number 3 - September 1989 


\section{Ideology, Doctrine, and Practices}

Doctrine is not ideology, though ideology serves as a premise for it. ${ }^{2}$ Doctrine is not tactics or strategy; it serves as the premise for tactics and strategy. Doctrine guides the principles of action of agencies and, hence, their behavior, but it also is based on experience with such behavior and therefore corrected by it. Doctrine answers the question, "What do we believe to be true and tested that could guide our actions?" For those who are doctrinaire, the question is absolute: "What is the established truth that our actions must follow?" In any given field of endeavor, doctrine is the body of principles held to be true within that field. ${ }^{3}$

In the field of public service, doctrine is shaped on the one hand by ideology or political thought, which defines what is real in the political environment that surrounds government agencies, and on the other hand by existing practices-whether tactics or strategies-considered to have been validated by experience. Ideology as a term is used here in a value-neutral sense: It is simply the set of ideas with which we approach and grasp hold of the world. The ideas of political ideology are the categories within which we perceive what is real in the world and order those perceptions. In this sense ideology defines what is real in politics. ${ }^{4}$ In the context of American politics relevant to different doctrines of administration, ideology may be expressed by a political party or by a campaign that produces those who legitimately govern those who administer, such as presidents or legislators. If ideology answers the question, "What is the world like?" then doctrine answers the question, "What should we do about it?"5 In public administration usage, the term rarely appeared and had little salience as long as tactics and strategies went fundamentally unchallenged during the long period (inaugurated by the New Deal) of fundamental agreement on positive intervention by government in people's lives.

\section{Crumbling Doctrine, Evolving Doctrine}

Today, the coherence of quietly held doctrine has been fragmented, its guiding force become uncertain, its definition at issue. Origins of this fragmentation date back to the time of the second Hoover Commission, when the original fit between top-down bureaucratic theory and the political theory of positive government began to become unglued. ${ }^{6}$ More immediate causes may include the fragmentation of ideological assumptions about the nature of the political world in the 1970s and 1980s, the onslaught of changed technology, tightening of economic conditions, and the negation of utility of traditional practices under resource shrinkage. Public service doctrine today suffers, on the one hand, from a lack of ideological legitimation of traditional and still-ongoing practices: Traditional bureaucrats find themselves exercising principles and practices that often no longer have the political support of the Chief Executive. On the other hand, representatives of a new government ideology-ranging from Ronald Reagan to George Bush and their representatives-suffer from insufficient validation in, or relevance to, public practice of 
their own ideological assumptions about the nature of the reality that is being confronted. Because traditional ideology no longer clearly supports administrative practice, new political leaders are concerned that public servants understand and implement the administrative implications of new political ideology (Moe, 1985, p. 260; Sanera, 1984), even as traditional public servants are looking desperately for a body of principles and ideological supporters that can justify their practices (see Ingraham \& Ban, 1986, p. 159) in spite of the absence of Chief Executive authority that will approve of them. The need for explicit doctrine emerges primarily from the gap between political ideology and administrative practice. Old doctrine lacks ideological strength, new doctrine is still evolving and tested practices are relatively few, and potential synthesis of doctrine is suspended in the tension between new ideology and old practice.

Based on what we know of trends in politics, administrative practice, organization theory, and economics, what can we say about any emerging administrative doctrine?

\section{In Search of Doctrine}

Throughout the Reagan, and now Bush, administrations, it has become necessary to face a new political reality: Any emerging administrative doctrine must rest politically on a new foundation-on a resurgent bottom-up, marketoriented progressivism that has successfully challenged the tradition of top-down positive government. (On positive government, see T.H. Green, 1879-80 [1927]).

Attempts by traditional bureaucrats to recapture ideological justification for their top-down practices through claims to be acting in the "public interest" (Ingraham \& Ban, 1986, p. 159) probably miss the ideological test of doctrine. Doctrine must define what is possible in administration by reference to what is considered real in politics. Ideology reconceives politically what can be real for government. The ideological challenge to traditional bureaucratic doctrine is not that bureaucrats are unable to act in the public interest. Rather, it is that the field of actors concerned with the public interest is now considered broader than the arena of buraucrats and that some areas of the public interest now are being defined in terms of an aggregation of private interests outside of government altogether. On the field of political battle, bottom-up progressivism has successfully challenged the near-monopolistic claim of the federal bureaucracy to be the prime, central, or even sole actor of administration. This claim can no longer be taken for granted when it comes to implementing, and even sensing (Blacksburg Manifesto, 1984), the public interest.

\section{Combining Centralization and Decentralization}

Under the Reagan and Bush administrations, one of the paradoxes that confuses emerging administrative doctrine is that bureaucrats are asked to be both centralized and decentralized; they must be responsive upward to a more centralized fiscal policy center in the office of the Chief Executive even as that 
Chief Executive swears off the traditional role of evoking and synthesizing a coherent public policy in many issue areas. ${ }^{7}$ Contrary to those still demanding an image of strong leadership at the executive center, ${ }^{8}$ an ideology respecting market forces makes cautious and moderate managership a tenet resulting from a view of reality that should not be blamed on personality. At the same time, the executive and like-minded cabinet officers insist on a wider distribution of the implementing function among program managers, networking with the private sector and privatization itself, and-borrowed from the private sector-quality- and effectiveness-related consultation with street-level functionaries on the firing line.

In terms of models for public management (Stillman, 1982, pp. 4-12), the bureacrat finds assumptions that are anathema to the classical top-down model of the professional administrator (taken for granted since the days of Franklin D. Roosevelt). Despite some modifications contained in the literature of organization democracy and coproduction, the professional bureaucrat was assumed to know better than anyone else how to run programs. Today this assumption is challenged by a strange, and as yet unclarified, mixture of models for decentralized program execution that might trace ancestry to traditional and vanguard business practices (a classical corporate model and a postmodern one), to the New Federalism of Nixon and Reagan, and, possibly, even to assumptions that citizens know best-as reflected in the community action model of the Johnson administration (Altshuler, 1970; Kotler, 1969; see also Seidman \& Gilmour, 1986: chap. 6).

Perhaps the most difficult insight for established bureaucrats to swallow may be that the ideology of the "Reagan Revolution" led the followers of Reagan-and now Bush-to prefer ways of policy implementation that do not involve an administrative doctrine at all-simply because that would require setting up, maintaining, or strengthening existing bureaucracy when direct funding or vouchering of public choices among private goods and service providers is preferred. For both the Reagan Revolution and the Bush era it is more appropriate to speak of a preference for implementation doctrine rather than administrative doctrine.

\section{Administering Growth, Implementing Control}

Federal policy and therefore programs have suffered an ideological split-between how policies of control and policies of growth are conceivedthat has produced a tendency away from the concept of administration on the doctrinal level. The majority of voters in presidential elections, for example, although not abandoning expectations of governmental safety-net operations in the social field, have selectively turned away from the public sector for expectations of economic growth-the defense industry being a major exception that is conveniently overlooked. Reaganite deregulation excised entire subfields of federal control activity from the purview of regulatory agencies, designating them vehicles for privately funded and implemented economic growth and development. 
At the same time, the private sector still looks to the federal governmentand the federal government still provides-for those legal and economiccontrol activities guaranteeing the stability of the private sector markets for which bureaucracy was originally invented (Weber, 1968, pp. 162-164) and which private corporations, with their now global reach (Barnet \& Mueller, 1974), are not yet able to fully control (Committee for Economic Development, 1980)..$^{9}$ The Bush administration's proposals to control the savings and loan industry may be considered an example of a mixed governmental response to such a traditional problem, providing strengthened bureaucracy yet relying on largely after-the-fact policing rather than direct bureaucratic controls or operation of private-sector enterprise.

Thus, although not consistent, bailouts for automobile companies, aircraft companies, banks, and savings and loan associations are common, reflecting a different set of assumptions when it comes to the need to provide economic stability and the need to loosen controls to facilitate growth. Growth policy rests on the economic assumption of a hidden hand that aggregates the private profit of interest of each enterpriser into the public good of all citizens. Control policy assumes just the opposite, as expressed in Reagan advisors' justification for recommending a $\$ 50$ billion to $\$ 100$ billion bailout of their own administration's deregulation of the savings and loan business: "When you encourage irresponsible management, you are almost certain to get it" (Kilborn, 1989). At first it may be confusing that when levels of regulation are considered, Reagan's and Bush's policies are deregulatory. When the idea of maintaining economic stability through minimal regulation is contrasted against the previous concept of government administration of the economy, however, what emerges is the insight that Reagan-Bush implementation doctrine is regulatory rather than administrative (see Seidman \& Gilmour, 1986). Thus, for example, intervention of traditional cabinet and independent administrative agencies, although not totally avoidable, has been limited in proposals for remedying the savings and loan crisis; reliance has been placed on tighter rules that must first be broken before they are policed. The centripetal pull of such a policy reflects an ideological center of gravity that places ultimate faith in markets and not in government expertise at the doctrinal level.

\section{Impact of New Doctrinal Premises}

Among federal agencies, this means differentiated doctrine depending on whether the agency is considered predominantly an old-fashioned control agency or one now charged with either stimulating or getting out of the way of growth or technological and economic transition. Operationally, within agencies, the new ideological demands are reflected in increased use of alternate quality- and effectiveness-oriented designs and techniques rather than dependence on traditional bureaucracy limited to quantity and internal efficiency.

Theoretically, doctrine seeks an evolving organization theory that fits postmodern conditions and demands. Economically, the burden of national debt and rising debt service constrains emerging doctrine by imposing the strongest top-down financial controls that the country has ever experienced. 
In terms of premise, the new doctrine is to: question who should deliver which public service, leave control operations to bureaucracy but shift toward regulative policing rather than direct management, give growth operations to private contractors, trust citizens rather than administrators, get effectiveness not just efficiency, use both top-down controls and direction of administrators and bottom-up knowledge of employees, organize for both retrenchment and quality, and audit to maintain liquidity for debt service. Such doctrine reflects strong operational concerns, paralleling business operations, and, in keeping with the ideological base of three presidential administrations, deemphasizes use of the federal civil service as the vehicle for imposing principles of social equity, social justice, and other "traditional" public service concerns. Select moral issues raised by the religious right are the exception. ${ }^{10}$

\section{Ideology and Political Doctrine}

Who should deliver public service? Politically, the ideology underlying administrative doctrine since the New Deal has been let government do it. This premised the ascendancy of faith in expert administrators, increasing reliance on tax extraction, and top-down distribution of public services and controls. Since its heyday at the turn of the century, the country has lost some of its faith in the type of progressivism that promoted strong government as the necessary tool for advancement into a better life for the country. Modernists, since the New Deal, have retained confidence that with the tools of technical rationality-science and bureaucratic organization-the world was becoming a steadily better place in which to live.

Reflected in the limits placed on science through the growth of science and technology policy (Lambright, 1976), is the absence of the original ebullience and enthusiasm of blind faith in progress. At the same time, organization policy no longer relies exclusively on bureaucratic doctrine (see Calista, 1986; Peters \& Waterman, 1984).

Ironically, however, Americans have turned back to the other vehicle of the progressive faith: democracy. Of the former faith, Waldo (1984) wrote,

At the heart of Progressivism was a basic conflict in social outlook.

This conflict was between those whose hope for the future was primarily that of a planned and administered society, and those who, on the other hand, remained firm in the old liberal faith in an underlying harmony, which by natural and inevitable processes produces the greatest possible good if the necessary institutional and social reforms are made.

Now, since the late 1960s and continuing into the 1980s, large segments of the population on both the left and the right have been challenging or turning against the one method of implementing progressivism that had dominated since the New Deal: top-down planning and administration. These people no longer trust in a top-down progressivism that contends that the future has to be "given shape from above" by creating or maintaining "a strong right arm for the State in the form of an efficient bureaucracy." Rather, their optimism much restrained (so that a better term for them might be neopopulists), those still 
holding hope for continued national growth turn to a residual belief in the other method of progressivism (if not in the optimism of progressivism itself): the bottom-up method for achieving goals. This has created some strange bedfellows.

Many of those who still have something to gain from positive social programs of a strong government join with those who see themselves only as victims of such government's power to extract taxes in one ideological position: that people who are on the bottom have the best judgment about what is good for them. In the case of tax resisters, this belief manifests itself in the actions of voting down taxes and supporting tax-resistant popular leaders, including presidents. In the case of social program clientele, who believe in the need for tax extraction, there is the belief that those at the bottom know something about how those taxes ought to be used. In a strange, both unifying and divergent sense, both groups of citizens believe, along with the old bottom-up progressivists, that "the Future must well up from below" (Waldo, 1984, p. 18). The result is that those who have espoused community participation and coproduction since the late 1960s potentially find that in their theory of organizing programs of service delivery (though not in their class position and reliance on government for tax extraction and policy formulation), they are closer to those who, since the beginning of tax revolts in the 1970s, have suggested privatization. Both believe in citizen expertise.

Traditional clientele groups and tax resistance movements look toward such residual political tools of bottom-up progressivism as the initiative, the referendum, home rule, and proportional representation. The more marketoriented tax resisters rely upon the first two, and the clientele groups rely upon community-based versions of the latter two.

For those dependent for their election on sweeping movements that cut across traditional interest groups and party lines, political doctrine is the endorsement of bottom-up progressivism. Whether it rears its head as community control of the public sector or as tax revolt (preferring to pay indirect taxes to private institutions perceived as effective rather than relying upon public institutions no longer perceived as efficient), bottom-up progressivism already has paid dividends to those presidential candidates willing to play to it.

A historically unique combination of design theory and carriers of that theory emerged. Top-down progressives engaged in an alliance with the doctrine of efficiency, but bottom-up progressives now had their own doctrine: effectiveness.

We have learned from Max Weber (1958) that every guiding idea seeking to become concrete needs a carrier; to the extent that this is true, it would be dangerous to dismiss the design ideas of tax-resisting progressives. Those who believe in the democratic design of government institutions now can claim a normative organization theory of their own: not only privatization but design and management of public and private institutions based on the bottom-up knowledge of those with their hands on the work - a theory already implemented by leading businesses and industries. The convergence of bottom-up blueprints for organization design from disparate sources boggles the mind; coproduction advocates, supposedly aligned with the political left, now 
provide potential theory and practical experience for supposedly conservative tax resisters (like adherents of Proposition 13). This group believes that because the private sector works bottom up based on market need, it can implement government policy better than top-down public administration. Yet, bottom-up progressives reject the claims to entitlement that originally were expressed on behalf of lower-income clientele by the coproduction movement.

At the same time, corporations provide similar bottom-up theory and practice based on a quite different motivation. Although ideological differences may keep left and right apart, their organization theory is not totally incompatible and in some ways may seem to converge. What is already clear is that an adhesion of organizational design theory to bottom-up progressive (or populist) democrats has occurred, which is unprecedented and, to say the least, logically unanticipated. Organization and democracy long had been held to be in contradiction. Not since the nation's republican solution to the desire for bottom-up rule and the Wilsonian politics/administration split that ironically reconciled democracy and bureaucracy has there arisen a compromise or synthesis such as the one hinted at by the possible combination of the new populists' political theory implementation, which opposes big government and the taxation to fund it and puts forth a new organization theory (a "negative" administrative doctrine) suggesting that those outside government, if not at the bottom of society, best know how to implement government work.

If we divide history into eras dominated by top-down progressives and bottom-up populists, as far as design ideas are concerned, then we observe that progressives in the first period were graced with a clear-cut design theory. Populists, because of their democratic commitment, had no theory and could not imagine one: The hidden hand of the market had its own grand design. In the current period, however, top-down progressives are losing presidential election after presidential election presumably because their top-down solutions to solving the nation's problems, and the extractive and redistributive processes that go with these solutions, are perceived as antiquated. Meanwhile, bottom-up progressives, although tacitly accepting a modification of pure market theory that puts government into the role of ultimate arbiter and guarantor of markets, have shifted their faith in the creativity of the individual entrepreneur to a faith in the creativity of hands-on corporate management, developing a nonpublic organizational theory that focuses less on mere efficiency and social control than on effectiveness and economic growth. Emerging in renewed market theory is a faith that the market will favor those who are attuned to a developing need for quality goods and services-and actively do something about it (see Stockman, 1987, p. 9).

\section{Implementation/Administrative Doctrines}

How should public service be delivered? This question cuts to the core of administrative or implementation doctrine as guidelines for the means of the delivery of what traditionally have been considered public ends. During the two Reagan administrations, Reaganites themselves made some very clear statements about the premises underlying the guidelines they saw as appropri- 
ate for choosing strategies and tactics of service delivery. Nevertheless, doctrine remained confused.

Confusion arose from two sources: (1) traditional administrators imbued with bureaucratic doctrine resting on top-down progressivism refused to believe that a change in ideological premises demanded a change in doctrine; (2) the politicians and the administrators of top-down progressivism, under the pressure of both ideological challenge and exigencies of cutback managements, failed to develop an adaptation of their ideology to new realities and new administrative doctrine.

As a result the only clear doctrine on the books today is Reaganite implementation doctrine. It remains an irresistible force that, in the Bush administration, has had its impact blunted by (1) the immovable practices of residual top-down progressivist strategies and tactics still in place, and (2) the inability to subject some central premises to the test of experience. In short, Reaganite doctrine, apart from its positive can-do elements, may have been so loaded by negative and untestable (if not paranoid) ideological premises about the reality of the agency world and its inhabitants that some of these premises got in the way, preventing the doctrine from becoming a message with a clear and unequivocal point. For example, Reaganites wanted both to replace existing bureaucratic practices with alternate methods and to immediately paralyze, if not destroy, what they perceived as the political will of traditional bureaucrats. The result was a positive doctrine distorted by its own negatives (Hummel, 1987, chap. 6). Reaganites did not simply offer a better alternate doctrine based on premises that had a legitimate history in the country, they also wanted to put an end to both the historical legitimacy and the future of the doctrine they sought to replace. The residual progressivist practices themselves were unable to evoke a sense of enthusiastic subscription to the legitimacy of the principles and practices of top-down administration. Because these had become so routine since the days of Franklin D. Roosevelt, few had thought to bring up to date the legitimating premises on which they rested and to which constituencies of latter-day top-down progressivism could subscribe.

\section{Reaganite Doctrine}

Practically, within the administrative agenda during the Reagan era, confusion reigned as government agencies and their managers faced a transition of crisis proportions. New tasks were assigned, traditional goals were taken away, old methods no longer worked under retrenchment, and new methods of implementaton were insisted upon by a new constellation of interests in the design of public bureaucracy policy. Where traditionally the design of government institutions had been left to a coalition of goodgovernment groups and civil servants' associations (Levine, 1985, p. 26) espousing progressive notions and imposing doctrine from the top, a populist reaction in large-scale movements now cuts across interest groups and political parties and helps responsive presidential candidates from Carter to Reagan and Bush into the office. Voters who opposed tax extraction, although 
not bringing the federal bureaucracy to its knees, had at least participated in deciding how much bureaucracy there should be in endorsing new formulas of redesign; privatization was a favorite solution. Ultimately this would mean agencies would be transformed from an administrative function involving hands-on in actual service and goods delivery to a regulatory function involving the supervision of external contracts.

Within government, two separate premises begin to underpin two distinct types of operational doctrine: control doctrine and work doctrine. Under the control doctrine, premised on supply-side economics, government expenditures and the resulting tax burden are viewed to be drags on economic growth; fiscal control must be exercised over the bureaucracy for policy purposes informed by the values of tax resisters and market ideologists. Control doctrine is aimed at keeping adherents of traditional doctrine from asserting the top-down role of sensing problems and deciding on solutions. It also serves the general purpose of guaranteeing essential stability of the markets so that the released market forces can play and function safely. Applied to the bureaucracy, control doctrine advocates traditional efficiency techniques, such as those reasserted by the Grace Commission. At the same time, oversight is shifted away from Congress and its affiliated interest groups to the Chief Executive, his constituencies in cross-cutting movements demanding relief of the tax burden, and traditionally designed and managed corporations. Control doctrine is implementation and regulatory doctrine - not administrative doctrine. Within agencies, the tools of control doctrine are the budget and the audit. When markets need to be controlled, as in the extreme case of market instability, safety-net operations may require some traditional management controls but, even then, tighter rules, which are policed and enforced after private entrepreneurs are given a chance to violate them, are encouraged. Such external regulatory doctrine simply raises the costs of doing business against the rules; government management is not imposed directly on business.

Work doctrine, although premised on a second assumption of supply-side economics - unleashing of private creative energies in the absence of government expenditures-might seem to be a counterpoise to control doctrine, but actually they work hand-in-glove. If enterprises carrying out contracted goods- and service-providing functions can develop their own expertise and operations in the private sector, then expertise-and experts-need not be duplicated in the public sector agencies, which simply oversee contracts or other indirect market-expanding reimbursements. Thus, for example, the Bush proposal for a tax rebate for day care, instead of directly funding and controlling day-care centers directly, can be seen as a government activity that creates or expands the day-care market and takes care of the family needs of at least middle-class constituents without imposing government controls or government operation of programs. Occasionally, under the work doctrine the creativity of those who design and operate programs-whether in government institutions or outside-is prized as long as these activities take place within the general policy guidelines of control or regulatory doctrine. 


\section{Control and Work Doctrine in the Reagan Era}

For federal bureaucrats, the often tension-producing dialectic of control doctrine and work doctrine was clearly evident in the more successful operations of the Reagan era and accounts for the strange admixture of centralization of policy at the staff level (see Sanera, 1984, pp. 514-515) accompanied by a relatively more relaxed attitude toward line operations than the traditional bureaucracy had produced. This is reflected in the characteristics and attitudes of "supply-side managers" (Carroll et al., 1985, pp. 807-808).

The concepts of supply-side and demand-side carry political doctrine (responsive to those who supply revenues, rather than those who demand services) directly over into implementation doctrine. Since the president is, within the American constitutional system, naturally the only national figure who can mobilize and respond to national movements (in this case, revenue resistance), managers drawn to the supply-side ideology will tend to look to the values of the president and his movement constituencies, while facing the reality of everyday budget and iron-triangle relations with Congress and its demand-side interest-group constituencies. In this context, supply-side managers face a terrible tension: they must adopt practices that fit into a bottom-up progressive doctrine of program effectiveness and continue to meet the traditional efficiency and control standards of upward-directed political responsiveness oriented toward members of Congress and interest groups more familiar with traditional bureaucratic practices.

Despite such tensions, the new supply-side manager cannot be understood unless we become aware of an underlying vision of reality with which the supply-side manager, along with other bottom-up progressives or latter-day tax-resistant populists, easily identifies. In short, negative administrative doctrine imposed during the Reagan era reverted to bottom-up progressivist assumptions as interpreted by current-day revenue-resistant populist movements of the middle class, so successfully mobilized and represented by the president. Based on the premises of bottom-up progressivism, control doctrine expanded from a Congress-and-interest-group orientation, in which groups could permeate the bureaucracy before, during, and even after implementation, to an executive orientation, ultimately yielding what Walter Dean Burnham calls "a divided block regime." (cf. 1989). With the exception of national defense and foreign policy, the executive in turn could always use populist progressive appeals to resist the interest-group demands that had dominated public administration since the New Deal. Supporters of the work doctrine, in turn, began drawing for inspiration on that group in society perceived as having the most experience in managing work outside of government: business, specifically vanguard corporations, pursuing standards of growth through effectiveness and excellence.

\section{Grounding Emerging Doctrine}

Administrative or implementation doctrine must be validated, on the one hand, by viable ideology tested on the political battlefield and, on the other, by 
the workability of its practices in the human and economic environment. Given revolutionary changes in the economic environment-deficits and retrenchments that cause many bureaucratic routines and assumptions to be unworkable - and given the defeat of top-down progressivist ideology in three recent presidential campaigns, neo-top-down progressives have experienced difficulty in developing a new administrative doctrine appropriate both to the new political constraints and to economic constraints. They are further handicapped by vanguard business practices that seem to endorse the assumptions of their enemies, the bottom-up populists.

Just about the only factors that work in favor of a neo-top-down progressive doctrine are legal tradition and the visionary myth of the American political culture. The legal tradition of positive government operationally goes back not only to the New Deal but to the Brandeis briefs. The grand visionary myth of the American political culture states that the country can be conceived as a national community that must progress ever onward under the leadership of great presidents to ever-greater social equality and social justice (Roelofs, 1976). But the source that judges the legal tradition, the Supreme Court, increasingly has been unhearing of the voices of tradition, and in at least three presidential elections, the electorate has been blind to the visionary promise of the culture.

Bottom-up progressives have captured political ideology and business practices and also have responded to the conditions of economic constraint: unwillingness of the middle class to continue carrying the tax burden for others and the resulting need for retrenchment of those programs that do not directly benefit the middle class or employ their expertise. Top-down progressives have sufficed with established bureaucratic practices (somewhat amended through community participation tactics), the legal tradition going back to the New Deal, and an attempt to mobilize the demand-size class. The result has been public administrative doctrine unsupported by a new and increasingly salient ideology and lacking the support of the Chief Executive. On the other side, it has been thought one could do without a public administrative doctrine by either simply redirecting the conclusions of ideology, economic constraint, merging business practices back into the private sector (privatization), or getting rid of public programs-in short, replacing administration doctrine with a wider implementation doctrine that would be partly antagonistic to the former.

\section{Top-Down Progressives: The Loss of Ideology}

On the other side of progressivism, a loss of faith seriously damages the possibility of justifying even the most familiar and routine practices of administration, in place since the New Deal, as legitimate. Challenged are the premises that there is a public interest, that the variety of private interests can be aggregated into the public interest, and that government agencies represent particular interest, and bring them together into a public interest. Only faith in the president as a center remains. Increasingly, however, the president 
is perceived by the mass of citizens as a symbolic or even spiritual center, reflecting needs of the soul. The traditional president since the New Deal reflected needs of the body. In practice, the president now is linked on the mythical level directly to masses of movement voters, who deny government the wherewithal to take care of fellow citizens' material needs and who see in him the advocate of spiritual dogma. ${ }^{11}$ Ideologically, the president reflects the operational concerns of private interests seeking to pursue their private good in a relatively open market protected by government from ultimate risks. Rather than being the author of public policy, he is in effect the deputy of the market's hidden hand. There is a decline of reliance on the filtering and balancing activity of the agencies or even of Congress. The result is that two separate lines of implementation are established: one from the president to the agencies, the other a coalition between agencies and Congress.

White and McSwain (1987) provide a summary of the premises and administrative working principles (what we would call doctrine) that used to characterize the unifying orientation of the "traditional era" in American public administration. When these are juxtaposed against contemporary disillusion, we get a sense of the extent to which traditional doctrine is endangered because many citizens can no longer buy into its ideological premises.

Still, residual top-down practitioners in the public service attempt to uphold existing practices citing their long record of validation going back to the New Deal. These practices are in essence program practices. In general, they rely on assumptions of representation of a specific community of interests by each agency, professional and administrative expertise useful in sensing problems and developing solutions, and neutral competence in service delivery within the domain defined by the specific community of interests. In situations for which the division between springboard and market policies applies, agencies and program managers will insist on more or less top-down control: more for springboard activities, less for market-oriented programs. Overall, a split is accepted between responsiveness to political appointees at the top administrative levels vis-à-vis compliance with budgeting procedures and the maintenance of the effectiveness of local top-down programmatic control by professional managers.

Absent is the hope of discovering a national synthesis of public interests through processes involving the president, the Congress, and the agencies. If agency heads ever were perceived to be responsible for discovering the interest of their clienteles, now increasingly they had to yield their leadership as professional managers and experts in methods of delivery to influences stemming from the private sector. The president could no longer be relied upon to be the chief legislator who would, in the next rank of administrators, discover the public interest; rather, the president now emerged, despite deficits externally, as the central internal comptroller of the budget and ultimate "umpire" when the fight for the right in the market became too violent or too hurtful. 


\section{Convergence?}

Underlying all this is a profound loss of faith in the dominance of hierarchy not only in public but in private administrative practice. Hierarchy is under attack across the board. Just as the public Chief Executive emerges as comptroller and attempts to control through the budget, private chief executive officers similarly exercise financial and budgetary controls, except that in private organizations, the reliance on local program management is more advanced for different reasons: effectiveness and quality are seen as the cause and hope of organizational survival, whereas in government, local program management still depends on efficiency claims aimed at those who authorize the budget-Congress. In this attack possibilities of convergence seem apparent; it might appear at first that because both neo-top-down progressives and bottom-up progressives question hierarchy, they might join forces in looking toward community-based practices. The question is what is meant by community.

It certainly is true that top-down progressives, since the Great Society, have looked toward community input in the design of policy (see Jun, 1986). This is reflected in inclusion of community voices in such far-ranging decisions as environmental impact or such local examples as community school boards and planning boards. What continues to make top-down progressives topdown, however, is that they do not perceive community members as sources of expertise but of demand. In turn this legitimates the existence of bureaucracies in which policy and program design are centralized and left to experts. What further differentiates community-sensitive top-down progressives from bottom-up progressives is a difference in the definition of who is included in the community.

To top-down progressives, the community is the whole of those who demand material services. Community is, in fact, a layer at the bottom of the social and economic pyramid from which demand and legitimation issues spring forth. To bottom-up progressives, the community is the whole of those who are called upon to give up supplies, specifically taxes; within the social and economic pyramid, these are the members of the middle class. It is to the citizen-expertise of members of this middle class, mobilized and developed in their role as members of business corporations, entrepreneurial to large, that bottom-up progressives also look for solutions to problems of policy implementation. As a result, bottom-up design of implementation practices is always linked in their minds to the question of how much these are going to cost them-or, on the upside, whether these practices can be profitable. There is an iron link of interest between being on the supply-side, in terms of paying for public goods and services, and possessing the expertise that, by defining public goods in private terms, can reduce the cost of implementation. Reducing the cost makes it profitable for the very class that defines which goods government can legitimately expect the middle-class public to pay for.

In short, the "bottom" for bottom-up progressives is not as far down as the "bottom" that legitimates top-down progressives. This truncating of the bottom of the social and economic pyramid also leaves the bottom-up progressives more receptive to business standards for public projects-drawing on tradition- 
al efficiency standards when it comes to unavoidable expenditures for the demand-side lower class and advocating effectiveness standards of the latter-day corporate ideology of excellence and quality when it comes to products and services that impact directly on themselves. The result is an essential coherence of interests that grounds the emerging bottom-up adminstrative doctrine both in the interests and the business experience of advocates and practitioners.

On the other side, neo-top-down progressives are not so lucky in the coherence of their practices and ideology. Their belief in the supremacy of administrative experts is not at all touched by the recognition (of the more advanced of them) that the exercise of such know-how must continue to be legitimated-and that such legitimation can be obtained from those who express demand. Since the demand-side class is constantly growing, of course, the hope is that growth can be retained or refreshed by continual expansion of the demand base. However, whereas practices and ideology are perceived as properly issuing forth from members of the same class among top-down progressives, practice remains the province of the expert class among top-down progressives even as they bow toward political legitimation of their ideology by those they serve.

In short, despite apparent parallels in questioning the hierarchy concept on both sides, hierarchy of knowledge remains the icon of administrative doctrine for top-down progressives even as they bend toward bottom-up political legitimation through such devices as community-based organizations. Central policy control also is still present when neo-top-down progressives seek to outdo bottom-up progressives in privatization-for example, in the concept of mandated benefits in which business not only is allowed to design federally mandated programs (such as health care provision for employees) but to pick up the cost of financing them. ${ }^{12}$ For bottom-up progressives, hierarchy, at least in the realm of government, is given a fatal delegitimating blow by the coherence of the supply-side attack on tax extraction and the perception that those who pay are also those who have the expertise for design of implementation practices. If receptivity to new effectiveness-oriented business practices is added to this combination, then bottom-up doctrine has a triple strength anchored in the perception that (1) those who pay should decide what government does, (2) those who pay have the expertise to determine how government should do it, and (3) those who both pay and have the expertise also may be those who should carry out the what and the how. The political ideology resulting from supply-side economics, experience with and selfinterest in private-sector implementation practices, and acquaintance with emerging effectiveness-oriented strategies in the private sector support a bottom-up progressives' implementation doctrine from all sides. It does not help top-down progressives that postmodern organization theory not only leads the challenge to traditional bureaucratic assumptions under attack by bottom-up progressives but contains technical implications that, without their normative context (and revivified top-down progressive ideology), lend themselves largely to the support of bottom-up practices, especially as these emerge from the private sector.

Residually, top-down progressives looking for coherence are forced to 
assert, in competition with a widely accepted and politically and economically powerful ideology of property interests, a doctrine of top-down expertise. This is ideologically strange to America's democratic values and needs to be legitimated. But legitimation in this case has come traditionally from the demand-side lower class, which is not politically effective. At the same time, top-down practices are difficult to give up because they probably constitute the most thoroughly validated body of practical knowledge — validated according to the standards of scientific management theory and classical bureaucratic organization theory and within the epistemological assumptions of traditional top-down doctrine. In terms of evaluation, these bureaucratic routines fit well with the traditional standard of efficiency that still has salience in the iron triangles. Efficiency, however, plays into the budget-cutting hands of those who assert that programs that government can undertake must measure up to competitive private-sector efficiency standards and that even those governmentrun programs that are efficient may not be programs that bottom-up progressives will want to pay for. At the same time, top-down progressives find themselves resistant to the effectiveness or quality-oriented standards issuing forth from the private sector because effectiveness delegitimates the efficiency standards that must be maintained for iron-triangle politics and threatens to remove programs from the purview of such politics altogether.

\section{Summary}

Traditional public administrative practices without a sustaining ideology and ideology without a time-tested repertoire of public practices-out of neither can we expect to see the emergence of a new and coherent public administrative or implementation doctrine, the normative organization theory that any nation needs to enact political ideology and guide its public practices. At best, a national but corporate/federalist implementation doctrine replaces a public centralist administration doctrine. In such doctrine, the national arena becomes the mere marketplace for the private offerings of goods and services, and a national policy may result out of the aggregate of such offerings. However, at no stage of its development will it be a public policy openly deliberated and decided with the public interest at heart-nor is a coherent and systematic national policy possible on the international field. The means of implementation will be at the choice of private bidders, and, in a civilization in which means tend to become ends, this means public policy becomes the mere aggregate of private policy-a policy of infelicitous accident and unsolicitous technology. ${ }^{13}$ The crisis of administrative doctrine that public servants experience every day in attacks on their practices has at its base not only a profound shift in American political ideology but the question of whether the concept of a public administration can survive. This also is a question of private interests that seek to eliminate the distinction between public and private, putting the concepts of public goods and services, the public interest, and the Republic itself, at risk. 


\section{Notes}

${ }^{1}$ With these three questions Charles $\mathrm{H}$. Levine $(1985$, p. 30$)$ set the agenda for normative organization theory for the foreseeable future. I would like to dedicate this article to his memory.

${ }^{2} /$ would like to extend my thanks to my colleague Stephen Sloan, who, in conversation, first broached with me the possibility of applying the concept of doctrine, so familiar in the military, to the conduct of civil agencies. Similarly, I owe a debt to my colleague Douglas Kinnard for help with the definition of military doctrine as promulgated by the Joint Chiefs of Staff (1968). I owe to Charles Levine the parallel usage "doctrine = normative organization theory." I use the term here in the sense of ideologically informed principles that guide practices of administration or implementation. Use of the doctrine concept is not totally absent in studies of civil administration; see Seidman and Gilmour (1986, p. 333) who use the term doctrine, as in "the doctrine of organization" when referring to the structuring of federal administration. An early version of this article benefited from the comments and criticisms of Bernard Ross and Dwight Waldo.

${ }^{3}$ This raises an interesting distinction between doctrine and scientific law. Practices dictated by doctrine can be tested only within that framework of premises (assumptions about the nature of reality) that undergird doctrine. Within the polity, administrative doctrine originally is shaped by political preferences not just about what should be made to happen in reality but what reality is: what it looks like to begin with. For example, trickle-down theory in Reaganite economics is neither a scientific law nor a theory that can be tested in a context in which it will be found to be universally applicable as a scientific law would be; rather, it affects human behavior within a specific context of people to whom the theory is plausible (plausibility structures), whose actions are affected because they believe the theory to be plausible, and who systematically exclude from any attempt at validation premises and realities outside what is considered plausible. In short, in the social and political world, doctrine is the result of ideology tested within a world of believers whose view of reality-and therefore perceptions and actions-is shaped by that ideology.

The context of doctrinally guided perceptions and actions, its plausibility structure, is constructed first by ideology, which determines perceptions, and second, by actions conducted and validated within the framework of such perceptions. The test of a doctrinally guided practice is first whether it can be conceived, and therefore talked about, within the limits of the underlying ideology, and second, whether so conceived and named, it can be tested empirically within the limits of the prevailing plausibility structure.

It would be improper to criticize doctrine for not being empirically testable; empirical testability in the scientific sense assumes a world within which a rule, generalization, or law can potentially have universal validity. Social and political worlds, however, are defined by their cultural uniqueness, and the behavior of the citizens of such worlds is not human behavior in the abstract or in general but always human behavior in a specific cultural context. The concept of doctrine, like that of ideology and of doctrinally 
defined practice, is therefore more proper to social and political contexts of human behavior than is the concept of scientific law or of empirical validation. The confusion between validation by plausibility and validation by empiricity accounts for a great deal of the continuing surprise among policy analysts about why their scientifically validated insights find so apparently arbitrary use in political practice [see Kash \& Ballard, 1987].

In times of crisis, internally validated practices may be challenged as to their external validity. For example, standard bureaucratic practices justified within premises of New Deal ideology and tested in the appropriate plausibility structures may no longer work as well under conditions of resource shrinkage and therefore become susceptible to challenge by doctrine based on new ideology. Thus, for example, because the growth premise associated with the New Deal is negated by no growth or negative growth, standard practices, such as using career ladders and testing as methods to inspire motivation toward productivity, may no longer work. Those now disappointed by foreshortened career ladders and the futility of doing well on tests to achieve higher salary or status become susceptible to more plausible explanations for how the world works offered by competing ideology.

${ }^{4} \mathrm{I}$ am here deriving from the general Kantian position, that we apprehend reality through a priori categories of thought; a political corollary is that we apprehend political reality through previously held categories of political thought. Ideology, or an order of political ideas, therefore becomes the set of ideas by which we apprehend political reality. This definition was determined by H. Mark Roelofs (1976), who pointed out that the set of ideas by which Americans in general grasp their political reality is split in two. One set, which he calls by the technical term myth, "denotes the nationally shared framework of political consciousness by which a people becomes aware of itself as a people, as having an identity in history, and by which it is also prepared to recognize some governing regime within its community as legitimate" (1967:4). It is Roelof's purpose to distinguish this set of ideas from a more narrowly operational and often opposed set that he calls ideology, ". . . the framework of political consciousness, the set of ideas, by which a people, or at least its dominant, governing element, organizes itself for political action" (Roelofs, 1967: 4). I find this distinction useful but am here reverting to the more popular use of political ideolgy as the general set of ideas - whether it includes mythical or political action elements-through which groups of the politically minded look at the world and construe and construct political realities. My thanks to Dwight Waldo for asking me to more clearly define ideology.

${ }^{5}$ It is probably more useful to speak of agency doctrine rather than agency ideology when it comes to the conceptualization of what actions should be undertaken in a specific policy area, and how. Otherwise, despite earlier contributions of the agency ideology concept, there is potential confusion of vocabulary. A theory of doctrine seeks to differentiate concepts when their equalization would lead to overlapping terms for distinct phenomena as in the following statement: "One of the classic examples of such an agency ideology is the doctrine of strategic bombing held by the United States Air 
Force" (Peters, 1989, p. 197). In the present theory and in everyday use, ideology appears distinct from doctrine because it has different empirical sources: Ideology arises within the realm of party politics, doctrine arises within the realm of administration. In general, justificatory conceptualizations of reality underlie and are distinguishable from principles of actions that serve as guides to behavior. (For an earlier discussion of agency ideology see Selznik, 1957.)

${ }^{6}$ Again, I am indebted to Dwight Waldo for pointing out to me early origins of conflicts in administrative doctrine and in practice.

${ }^{7}$ Only if the vision of reality (ideology) of recent presidents like Reagan and Bush is understood, will it be possible to give a fair-minded interpretation to what, in terms of the past growth of a policy-defining presidency, must be seen as their "failure" to lead on national policy. For example, when President George Bush refuses to take a stand on gun control at a time when Washington, D.C., is described as the murder capital of the country, interpretation from within his own ideology would be that such issues must be formulated and ultimately decided from the bottom up, not from the top down.

${ }^{8} \mathrm{~A}$ typical example of judgment passed on the Chief Executive from the perspective based on assumptions of positive government is in Apple, 1989.

${ }^{9} \mathrm{~A}$ typical example is the Committee for Economic Development, Research and Development Committee (1980), who demanded both reduction of "nonessential regulatory constraints" on "productive investments" and a reduction of "uncertainties" in such investments.

${ }^{10}$ In this bottom-up progressive model, chief executives are increasingly supported by the Supreme Court, as an example, in the Court's striking down of the Richmond (VA) City Council minority business utilization plan. (See excerpts from Court Opinions in Voiding Richmond Contracting Plan, 1989)

${ }^{11}$ Following the early work of political theorist $\mathrm{H}$. Mark Roelofs (1976), we can detect in the development of American political culture not only a split between two separate and contradictory parts (what Roelofs calls ideology and myth) but a profound transformation of these parts. The New Deal attached mythical expectations of justice, equality, community, and great leadership to material goals. Despite great achievements these goals were frustrated more often than not by the operational realities of the political ideology, with relief on processes that extolled and protected the values of individualism, hard work, and the competitive acquisition of property, whether it be economic property or political property in an office of consituency. With the rise of religious fundamentalism, the social-conscience side of the American myth has become attached to needs of the soul-expressed in demands for acceptance by the national community under presidential leadership moral dogma-although three attempts by Democratic presidential candidates to reattach the national conscience to material goals have failed at the polls. (For the original distinction between the ideological and mythical parts of American political culture, see Roelofs, 1976.) I owe the idea of the transformation of mythical concerns from needs of the body to needs of the soul to Barry Shain (1989), who suggested the following 
division of these needs among contemporary Democrats and Republicans:

NEEDS OF THE BODY NEEDS OF THE SOUL

DEMOCRATS Community Based Individual Choice

REPUBLICANS Individual Choice Community Based

${ }^{12}$ Discussion of the mandated benefits concepts originating from Democrats is found in curent news items. For an example, see Dionne, 1988.

${ }^{13} \mathrm{~A}$ typical example of such policy, whose calculus can never be felicific because it is based on terms that are uncaring of public needs, is the replacement of the public good of peace by the privately tendered good of "permanent prehostility" offered through the "public" institution of the Pentagon (redefinition of peace by the U.S. Department of Defense reported Nov. 28, 1984, by ABC Television News). Similar results can be expected when the public exercise of criminal punishment becomes the privately offered warehousing of convicted prisoners.

\section{References}

Altshuler, A. (1970). Community control. New York: Pegasus.

Apple, R. W. (1989, May 25). The capital: How long can Bush continue to speak in timid cliches while the world of totalitarianism shakes? The New York Times (national ed.). p. 16.

Barnet, R. J., \& Mueller, R.E. (1974). Global reach: The power of the multinational corporations. New York: Simon \& Schuster.

Burnham, W. D. (1989). The Reagan legacy. In Gerald M. Pomper (Ed.) The election of 1988: Reports and interpretations (pp. 1-32). Chatham, NJ: Chatham House.

Calista, D. (Ed.). (1986). Bureaucratic and governmental reform. Greenwich, CT: JAI Press.

Carroll, J. D., Fritschler, A. L., \& Smith, B.L.R. (1985). Supply-side management in the Reagan administration. Public Administration Review, 45 (6), 805-813.

Committee for Economic Development, Research and Development Committee (1980). Stimulating technological progress. Qtd. in J. Diebold, Making the future work (p. 325). New York: Simon \& Schuster.

Court opinions in voiding Richmond contracting plan. The New York Times, January 24, 1989, p. 12.

Diebold, J. (1984). Making the future work. New York: Simon \& Schuster.

Dionne, E. J., Jr. (1988, December 2). Reagan debt legacy: His trap for democrats? The New York Times (national ed.). p. 11.

Green, T. H. 1878-90 (1927). Lectures on the principles of political obligation. London: Longmans, Green \& Co., Ltd.

Hummel, R. P. (1987). The bureaucratic experience. (3rd ed.). New York: St. Martin's.

Ingraham, P., \& Ban, C. (1986). Models of public management: Are they useful to federal managers in the 1980s? Public Administration Review, 46 (2), 152-160. 
Jun, J. S. (1986). Public administration: Design and problem-solving. New York: Macmillan.

Kash, D. E., \& Ballard, S. (1987). Academic and applied policy studies-A comparison. American Behavioral Scientist, 30 (6), 597-611.

Kilborn, P. T. (1989, January 11). Reagan advisers blame U.S. policy for savings crisis. The New York Times (national ed.). p. 1, 30.

Kotler, M. (1969). Neighborhood government. Indianapolis: Bobbs-Merrill.

Levine, C. H. (1986). The federal government in the year 2000: Administrative legacies in the Reagan years. Public Administation Review, 46 (3), 195-206.

Moe, T. M. (1985). The politicized presidency. In J. Chubb and P. Peterson, (Eds.), The new direction in American politics (pp. 235-271). Washington, D.C.: The Brookings Institution.

Peters, G. B. (1989). The politics of bureaucracy: A comparative perspective (3rd ed.). New York: Longman.

Peters, T. J., \& Waterman, R. H. (1984). In search of excellence. New York: Warner Books.

Roelofs, H. M. (1976). Ideology and myth in American politics: A critique of a national political mind. Boston: Little, Brown.

Sanera, M. (1984). Implementing the mandate. In S. M. Butler, M. Sanera, \& W. B. Weinrod, (Eds.) Mandate for leadership II: Continuing the conservative revolution (pp. 514-515). Washington, DC: Heritage Foundation.

Seidman, H., \& Gilmour, R. (1986). Politics, position and power: From the positive to the regulatory state (4th ed.). New York: Oxford University Press.

Selznick, P. (1957). Leadership in administration. New York: Harper \& Row.

Shain, B. Personal communication, spring, 1989.

Stockman, D. (1987). The triumph of politics: The inside story of the Reagan revolution. New York: Avon Books.

U.S. Joint Chiefs of Staff (1968). Dictionary of United States terms for joint usage (JCS Publication 6). Washington, DC: Government Printing Office.

Waldo, D. (1984). The administrative state (2nd ed.). New York: Homes \& Meier.

Wamsley, G. L., Goodsell, C. J., Rohr, J. A., White, O. F., \& Wolf, J. F. (1984). The public administration and the governing process: Reforming the American dialogue [Blacksburg Manifesto]. Dialogue - The Public Administration Theory Network, 6 (2), 1-17.

Weber, M. (1958). The Protestant ethic and the spirit of capitalism (T. Parsons, Trans.). New York: Charles Scribner's Sons.

Weber, M. (1968). Economy and society: An outline of interpretive sociology, G. Roth \& C. Wittich (Eds.), E. Fischoff et al. (trans.). New York: Bedminster Press.

White, O., \& McSwain, C. (1988, April). The Phoenix Project: Raising a new image of public administration from the ashes of the past. Paper presented at the First National Symposium in Public Administration Theory held in conjunction with the annual meeting of the American Society for Public Administration, Lewis \& Clark College, Portland, OR. 
Ralph P. Hummel is Associate Professor of Political Science and Public Administration at the University of Oklahoma. He is author of The Bureaucratic Experience, which he has presented in three editions to reflect the state of contemporary organization theory. 